\title{
Oxytocin infusion from Day 10 after oestrus extends the luteal phase in non-pregnant cattle
}

\author{
C. L. Gilbert, G. E. Lamming*, T. J. Parkinson*, A. P. F. Flint $†$ and \\ D. C. Wathes
}

Department of Anatomy, The Medical School, Bristol BS8 ITD, UK; *AFRC Research Group on Hormones and Farm Animal Reproduction, at University of Nottingham, Faculty of Agricultural Science, Sutton Bonnington, Loughborough, Leics. LE12 5RD, UK; and †Institute of Zoology, Regent's Park, London NWI 4RY, UK

\begin{abstract}
Summary. Oestrus was synchronized in 8 cyclic heifers by progesterone treatment (PRID), after which the animals were monitored for one control cycle to measure the inter-oestrous interval. Osmotic minipumps containing saline (controls, $N=3$ ) or oxytocin $(\mathrm{N}=5)$ were implanted subcutaneously on Day 10 of the second cycle, and removed 12 days later. Jugular venous blood samples were collected daily for measurement of progesterone, and every 2 days for oxytocin. In addition, blood samples were taken every $10 \mathrm{~min}$ from $1 \mathrm{~h}$ before to $3 \mathrm{~h}$ after minipump insertion for measurement of plasma 15-keto-13,14-dihydroprostaglandin-F-2 $\alpha$ (PGFM) and every $30 \mathrm{~min}$ over the same period for measurement of progesterone and oxytocin.

The lengths of the first untreated cycle in both groups of heifers were $20 \cdot 2 \pm 0.56$ (mean \pm s.e.m.) days compared with $25.4 \pm 0.81$ days after oxytocin treatment $(P<0 \cdot 001)$. Oxytocin plasma concentrations in treated animals rose from $<10 \mathrm{pg} / \mathrm{ml}$ to $70-500 \mathrm{pg} / \mathrm{ml}$ by $2 \mathrm{~h}$ after the start of oxytocin infusion and remained elevated until treatment was withdrawn. There was no increase in PGFM concentrations immediately after minipump insertion. Plasma progesterone concentrations were similar in treated and control animals but remained at mid-luteal levels for an average of 5 days longer in treated heifers. It is concluded that continuous administration of oxytocin can extend the luteal life-span in cattle.
\end{abstract}

Keyrords: oxytocin; cattle; corpus luteum; luteolysis

\section{Introduction}

Oxytocin and prostaglandin F-2 $\alpha$ (PGF-2 $\alpha$ ) are now thought to play an important interactive role in luteolysis in the ewe (for reviews see Flint \& Sheldrick, 1986; Wathes et al., 1986a). In cattle the role of PGF- $2 \alpha$ as a luteolysin is also well established. Pulsatile secretion patterns coinciding with luteolysis have been demonstrated (Kindahl et al., 1976a; Betteridge et al., 1984) and synthetic PGF-2 $\alpha$ analogues will reliably induce luteolysis when injected into cows at mid-cycle (Schams \& $\mathrm{Karg}$, 1982). However, the role of oxytocin in luteolysis in cattle is less clear. Oxytocin is known to be synthesized in the bovine corpus luteum (Swann et al., 1984; Ivell \& Richter, 1984), and patterns of release into the blood stream have been determined during the luteal phase (Walters et al., 1984) and periovulatory phase of the oestrous cycle after induction of luteolysis by synthetic PGs (Walters \& Schallenberger, 1984). A luteolytic dose of cloprostenol (a PGF-2 $\alpha$ analogue) on Day 12 caused a single episode of oxytocin secretion to be released 5-10 min later, but no subsequent pulsatile release pattern (Schallenberger et al., 1984). Vighio \& Liptrap (1986) showed the spontaneous pulsatile release of oxytocin and PGFM into plasma to be highly correlated in 5 out of 10 
cattle on Day 18 or 19 of the cycle, but no clear pulses of either hormone occurred during sampling of the other 5 animals. Abdelgadir et al. (1987) demonstrated that PGF-2 $\alpha$ could induce oxytocin release from Day 8 luteal tissue in vitro but were unable to elicit a response on Day 12 or 16 , whereas Barrett (1987) was unable to find any consistent effect of PGF-2 $\alpha$ on oxytocin release in vitro using luteal tissue of various ages. Armstrong \& Hansel (1959) and Hansel \& Wagner (1960) showed that oxytocin, when given in vivo as discrete injections on Days 3-6 of the cycle, produced an early return to oestrus, and this effect was abolished by hysterectomy. However, treatment on other days of the cycle had no effect. Similarly, Oyedipe et al. (1984) showed that oxytocin administered on Days 2-6 of the cycle caused an early return to oestrus characterized by lowered concentrations of progesterone and release of PGF- $2 \alpha$.

Accordingly, although there is good evidence to support the hypothesis that oxytocin and PGF$2 \alpha$ may be acting in a positive feedback system to control luteolysis in sheep, there is less direct evidence linking secretion of oxytocin and PG to the control of spontaneous luteolysis in cattle, and it has been suggested (Schams, 1987) that the endocrine processes leading to luteolysis in cattle and sheep may not be the same. Flint \& Sheldrick (1985) have shown that continuously infused oxytocin prolongs the luteal phase of the oestrous cycle in ewes, probably by preventing formation of endometrial oxytocin receptors. The object of the experiment described here was to test whether a similar treatment regimen could also extend the luteal phase in cattle.

\section{Materials and Methods}

\section{Animals and management}

The 8 Friesian cross Hereford heifers $(\sim 400 \mathrm{~kg})$ were housed as a group and fed silage and a concentrate mix daily. All were experiencing normal oestrous cycles at the start of the experiment. The heifers were then synchronized for oestrus by using progesterone-releasing intravaginal devices (PRID: Ceva Ltd, Watford, UK), which were in place for 12 days. Oestrus was detected by a combination of twice-daily observations of behaviour throughout the experiment and the use of tail-paint.

\section{Experimental design}

After PRID withdrawal the animals were allowed one complete untreated cycle and monitored for oestrus. At 10 days after behavioural oestrus, in the second luteal phase, osmotic minipumps (Alzet-model $2 \mathrm{~m} 12$, Alza Corporation, Palo Alto, CA, USA) were inserted subcutaneously over the chest wall behind the right elbow, under local anaesthesia. The minipumps contained oxytocin (Hoechst, Frankfurt, West Germany), $14.7 \mathrm{mg} / \mathrm{ml}$ dissolved in $0.9 \%$ (w/v) $\mathrm{NaCl}$ containing $0.01 \%$ acetic acid $(n=5)$, or vehicle only $(n=3)$. The minipumps were removed after 12 days. Each minipump was incubated for $1 \mathrm{~h}$ in $0.154 \mathrm{M}-\mathrm{NaCl}$ ) at $37^{\circ} \mathrm{C}$ before and after the experiment for oxytocin radioimmunoassay (RIA) to calculate the release rates.

\section{Blood sampling}

Blood was taken daily by jugular venepuncture into heparinized vacutainers, and centrifuged immediately. Plasma was split into 2 aliquants and stored at $-20^{\circ} \mathrm{C}$ until assay for progesterone and oxytocin. In addition, all animals were given an indwelling jugular cannula $2 \mathrm{~h}$ before minipump insertion. Blood $(6 \mathrm{ml})$ was taken every $10 \mathrm{~min}$ from $1 \mathrm{~h}$ before to $3 \mathrm{~h}$ after minipump insertion, centrifuged in a tube containing $0.2 \mathrm{ml} 6 \%(\mathrm{w} / \mathrm{v})$ sterile sodium citrate containing $2.5 \mathrm{mg}$ aspirin/ml and the plasma stored at $-20^{\circ} \mathrm{C}$ until assay for 15-keto-13,14-dihydroprostaglandin-F-2 $\alpha$ (PGFM). Every $30 \mathrm{~min}$ an additional $6 \mathrm{ml}$ blood were taken, centrifuged in a heparinized tube and the plasma stored at $-20^{\circ} \mathrm{C}$ until assay for progesterone and oxytocin.

\section{Radioimmunoassays}

Progesterone. Plasma samples were measured by the method of Hunter et al. (1986). Mean extraction efficiency was $86 \%$. The assay showed negligible cross-reactivity with other major steroids. The minimum detectable dose in plasma was $0.6 \pm 0.39 \mathrm{ng} / \mathrm{ml}$ (mean \pm s.d.). The intra- and inter-assay coefficients of variation were $10.4 \%$ and $14.8 \%$ respectively.

Oxytocin. Extractions were performed using a modified version of the method of Wathes et al. (1986b). Plasma (2-4 m!) was applied to a Sep-Pak C18 Cartridge (Waters Associates Ltd, Milford, MA, USA) which was then washed 
with $20 \mathrm{ml} \mathrm{10 \%}$ acetonitrile (BDH Ltd, Poole, Dorset, UK) in $0 \cdot 1 \%$ trifluoroacetic acid (TFA: Rathburn Chemicals Ltd, Walkerburn, UK) and the peptide was eluted with $3 \mathrm{ml} 80 \%$ acetonitrile in $0.1 \%$ TFA. Each cartridge was used twice. The mean extraction efficiency was $73 \%$. Extracts were freeze-dried and resuspended in $450 \mu l$ assay buffer, centrifuged at $2400 \mathrm{~g}$ for $20 \mathrm{~min}$ to remove sediment and assayed using the method of Wathes et al. (1983). Radioimmunoassay was performed on extracted samples and extracted buffer blanks. The antiserum used (85/2) crossreacted $1 \%$ with mesotocin, $0.03 \%$ with lysine vasopressin and $<0.001 \%$ with other related peptides. The minimum detectable dose was $0.2 \pm 0.05 \mathrm{pg} /$ tube (mean \pm s.d.). The intra- and inter-assay coefficients of variation were $8 \cdot 7 \%$ and $14.9 \%$ respectively.

PGFM. Assays were performed on diethyl ether-extracted samples after the method of Kaker et al. (1984) with an extraction efficiency of $75 \%$. The antiserum cross-reactivity was $8 \%$ with 15 -keto PGF-2 $\alpha, 0.7 \%$ with 13,14 -dihydroPGF-2 $\alpha, 0 \cdot 5 \%$ with PGF-1 $\alpha$, PGE-1 and PGE-2 and $<0 \cdot 1 \%$ with PGF-2 $\alpha$. The sensitivity of the assay ranged from 38 to $96 \mathrm{pg} / \mathrm{ml}$ plasma, with a mean minimum detectable dose of $32 \mathrm{pg} /$ tube. The intra- and inter-assay coefficients of variation were $22 \cdot 7 \%$ and $36 \cdot 2 \%$ respectively. All samples from each animal were analysed within one assay.

\section{Statistical analysis}

Data on behavioural detection of oestrus, plasma oxytocin and daily plasma progesterone profiles were analysed using Student's $t$ test. Results for plasma PGFM concentrations before and after the start of oxytocin infusion were pooled and Student's $t$ test or a blocked 2-way analysis of variance was used when appropriate.

\section{Results}

The subcutaneous insertion of oxytocin-containing osmotic minipumps raised plasma oxytocin concentrations in treated heifers to $89 \cdot 6 \pm 10 \cdot 25 \mathrm{pg} / \mathrm{ml}$ (mean \pm s.e.m., see Fig. 1) compared with $4.9 \pm 0.42 \mathrm{pg} / \mathrm{ml}$ in control animals during the treatment period. In 4 out of 5 treated animals the plasma oxytocin level was consistently high throughout the time of pump insertion but in the other animal (Heifer 1) the values were erratic with 4 results out of 7 being less than $20 \mathrm{pg} / \mathrm{ml}$ with a range of $3.5-170 \mathrm{pg} / \mathrm{ml}$. In the same heifer a very rapid release of oxytocin into the plasma after minipump insertion occurred, reaching levels of $475 \mathrm{pg} / \mathrm{ml}$ at $2 \mathrm{~h}$, compared with only $77 \pm 14.9$ (mean \pm s.e.m.) $\mathrm{pg} / \mathrm{ml}$ in the other animals (see Fig. 3).

The rates of release of oxytocin from the osmotic minipumps as measured by assay of saline incubations of the minipumps were $26 \pm 4.1 \mu \mathrm{g} / \mathrm{h}$ before insertion and $9 \pm 3.7 \mu \mathrm{g} / \mathrm{h}$ after removal from the animals (mean \pm s.e.m.). In Heifers 3 and 6 , the release rates after removal were relatively low $(0.53$ and $5.7 \mu \mathrm{g} / \mathrm{h}$ respectively).

Observations of behavioural oestrus showed that heifers receiving oxytocin by osmotic minipumps had a significant lengthening of their oestrous cycles by about 5 days over all control cycles (Table 1). The daily progesterone measurements (Fig. 2) showed that in cows receiving oxytocin the luteal phase was extended by 4-5 days with progesterone concentrations maintained at normal mid-luteal values. After the delayed luteolysis, the animals appeared able to initiate a normal oestrous cycle, as judged by increasing progesterone concentrations occurring at the expected interval (1-2 days) after the delayed return to oestrus. The heifer receiving an erratic flow from the osmotic minipump (No. 1) had the shortest extension of its test cycle over the control cycle ( 2 days).

Blood samples obtained at the time of pump insertion demonstrated a rapid rise in plasma oxytocin concentrations in test animals from $30 \mathrm{~min}$ after the start of infusion. There was no corresponding rise in the controls (Fig. 3). Plasma progesterone concentrations were unchanged throughout this time in the test and control animals, with no difference between the two groups (Fig. 3). During the same period, more frequent blood sampling (every $10 \mathrm{~min}$ ) and subsequent PGFM assay indicated that the increase in plasma oxytocin levels produced by pump insertion had no effect on mean PGFM output (Table 2). In addition, examination of PGFM profiles from individual animals showed no discernible alterations in patterns of release or pulsatile activity during the sampling period. All values fell in the range $39-142 \mathrm{pg} / \mathrm{ml}$, with the highest value being recorded in Heifer 5 (one of the control animals). 


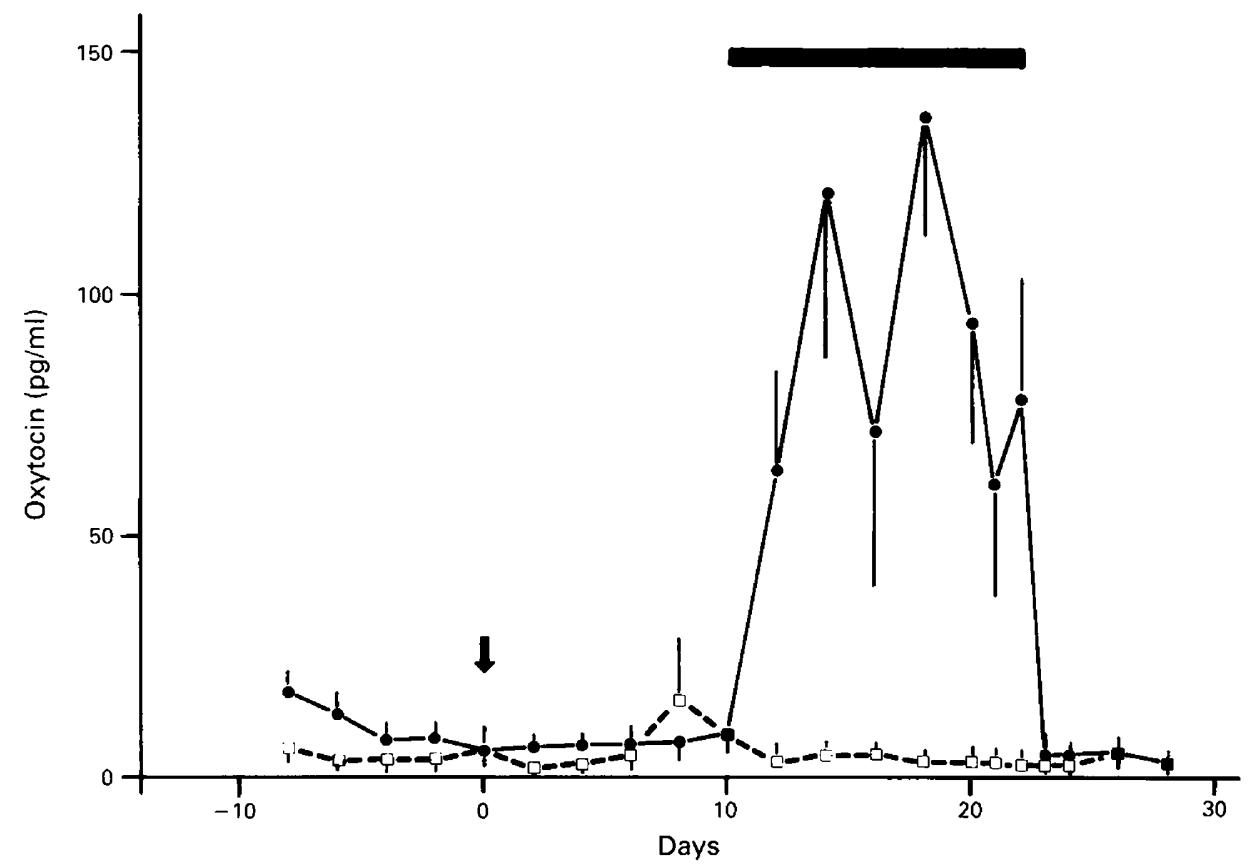

Fig. 1. Mean \pm s.e.m. plasma concentrations of oxytocin in heifers during minipump insertion. Samples were measured every 2 days except around the time of minipump removal when daily samples were obtained. $-=$ oxytocin infused $(\mathbf{N}=5), \square---=$ vehicle infused $(\mathrm{N}=3)$; $\downarrow=$ day of behavioural oestrus. Pumps were inserted on Day 10 and removed on Day 22 (solid bar).

Table 1. Length of oestrous cycles in oxytocin-infused (Days 10-22) and control heifers*

\begin{tabular}{lccc}
\hline & $\begin{array}{c}\text { Heifer } \\
\text { no. }\end{array}$ & $\begin{array}{c}\text { Control cycle } \\
\text { (days) }\end{array}$ & $\begin{array}{c}\text { Treated cycle } \\
\text { (days) }\end{array}$ \\
\hline Control heifers & 2 & 23 & 22 \\
(vehicle-infused) & 5 & 19 & 22 \\
& 9 & 19 & 19 \\
& Mean \pm s.e.m. & $20 \cdot 3 \pm 1 \cdot 33^{\mathrm{a}}$ & $21 \cdot 0 \pm 1 \cdot 00^{\mathrm{a}}$ \\
Treated heifers & 1 & 22 & $24 \dagger$ \\
(oxytocin-infused) & 3 & 20 & $23 \dagger$ \\
& 6 & 21 & 26 \\
& 8 & 19 & 27 \\
& 11 & 19 & 27 \\
& Mean \pm s.e.m. & $20 \cdot 2 \pm 0.58^{\mathrm{a}}$ & $25 \cdot 4 \pm 0.81^{\mathrm{b}}$ \\
\hline
\end{tabular}

*Most cycle lengths were determined by observation of behavioural oestrus. If oestrus was not observed $(\dagger)$, the cycle length was taken to be the time from one nadir in the progesterone profile to the next.

a $v$ s b: $P<0.01$ (Student's $t$ test). 
Table 2. Plasma concentrations (means \pm s.e.m.) of PGFM in heifers before and after minipump insertion on Day 10 of the oestrous cycle

\begin{tabular}{|c|c|c|c|}
\hline \multirow[b]{2}{*}{ Treatment } & \multirow[b]{2}{*}{$\begin{array}{c}\text { Heifer } \\
\text { no. }\end{array}$} & \multicolumn{2}{|c|}{$\operatorname{PGFM}(\mathrm{pg} / \mathrm{ml}) \dagger$} \\
\hline & & $\begin{array}{c}\text { Before } \\
\text { insertion } \\
(n=7)\end{array}$ & $\begin{array}{c}\text { After } \\
\text { insertion } \\
(n=18)\end{array}$ \\
\hline Control & $\begin{array}{l}2 \\
5 \\
9\end{array}$ & $\begin{array}{c}88 \pm 6 \cdot 2 \\
99 \pm 9 \cdot 2 \\
\pm\end{array}$ & $\begin{array}{c}52 \pm 5 \cdot 3^{*} \\
89 \pm 3 \cdot 4 \\
-+\end{array}$ \\
\hline $\begin{array}{l}\text { Oxytocin- } \\
\text { infused }\end{array}$ & $\begin{array}{r}1 \\
3 \\
6 \\
8 \\
11\end{array}$ & $\begin{array}{c}39 \pm 1 \cdot 2 \\
95 \pm 6 \cdot 8 \\
\underset{51 \pm 4 \cdot 1}{\$} \\
\end{array}$ & $\begin{array}{c}49 \pm 3.9 \\
94 \pm 3.6 \\
-\S \\
80 \pm 11 \cdot 1 \\
-\ddagger\end{array}$ \\
\hline
\end{tabular}

$* P<0.05$ compared with value before insertion.

tSamples were measured every $10 \mathrm{~min}$ from $1 \mathrm{~h}$ before insertion to $3 \mathrm{~h}$ after.

$\ddagger$ All values $<96 \mathrm{pg} / \mathrm{ml}$ (limit of sensitivity for that particular assay).

\$All values $<39 \mathrm{pg} / \mathrm{ml}$ (limit of sensitivity for that particular assay).

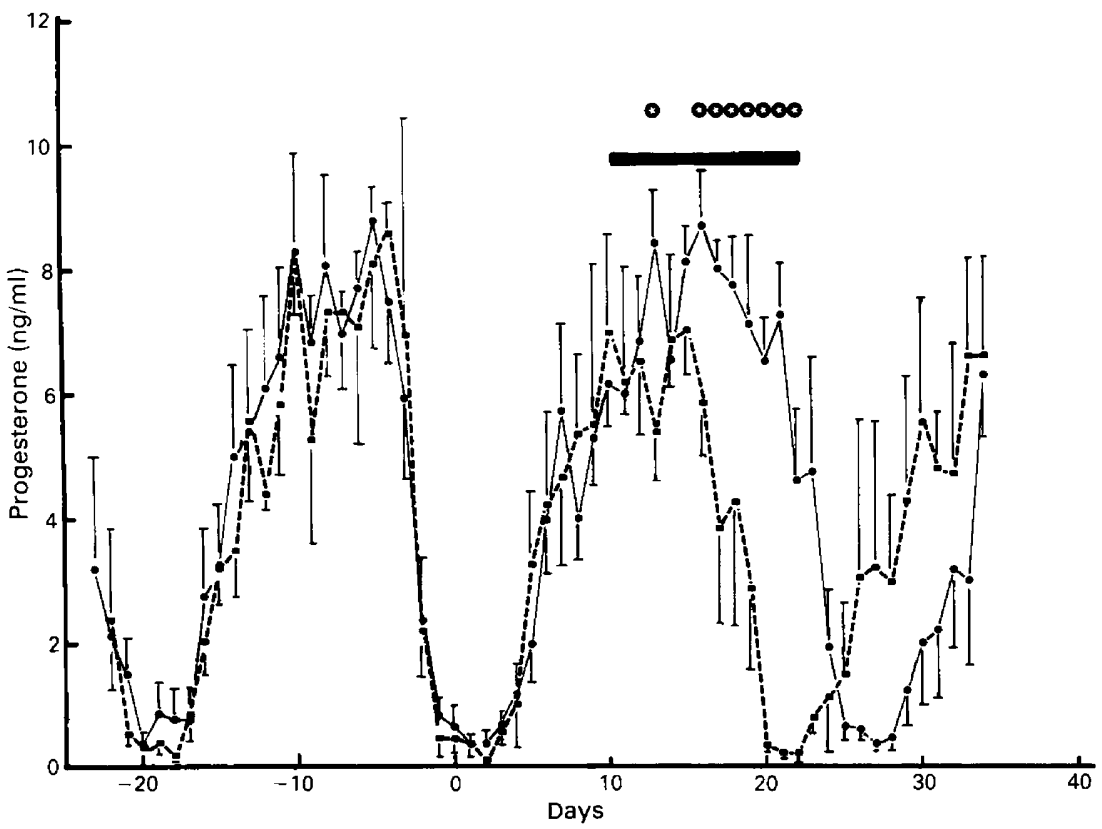

Fig. 2. Mean \pm s.e.m. daily plasma concentrations of progesterone in heifers throughout 2 oestrous cycles. Day $0=$ the day of behavioural oestrus at the end of the first (control) cycle. The bar represents the period of minipump insertion. $-=$ oxytocin infused $(\mathbf{N}=5)$, $=$ vehicle infused $(\mathrm{N}=3)$. $\bigotimes$ Indicates a significant difference between treated and control animals $(P<0.05$, Student's $t$ test). Differences between groups after Day 25 have not been shown as they represent a phase shift in the time of return to oestrus. 


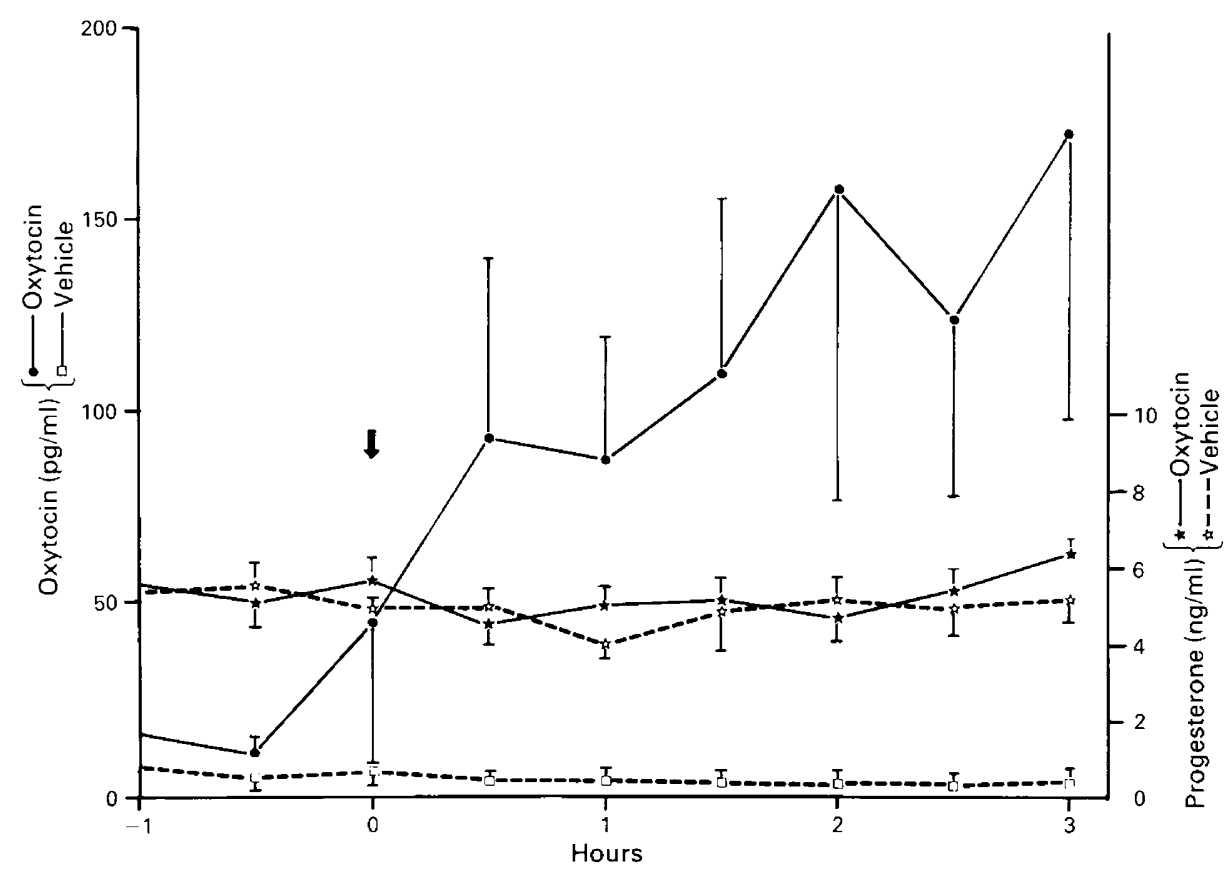

Fig. 3. Mean \pm s.e.m. plasma concentrations of oxytocin and progesterone in heifers during $4 \mathrm{~h}$ on the day of minipump insertion for infusion of vehicle only $(\mathrm{N}=3)$ or oxytocin $(\mathrm{N}=5) . \downarrow=$ time of pump insertion.

\section{Discussion}

These results demonstrate that continuous administration of oxytocin to cyclic heifers from Day 10 lengthened the luteal phase, and that subcutaneous osmotic minipumps were an effective means of achieving this effect. Similar results were obtained with ewes by Flint \& Sheldrick (1985) who showed that oestrous cycles could be extended by continuous oxytocin infusion; these authors attributed the effect to the high levels of circulating oxytocin preventing the formation of endometrial oxytocin receptors, thus preventing the PGF- $2 \alpha$ release necessary to induce luteolysis.

The results reported here differ from those of Kotwica et al. (1988) who concluded that no alteration in cycle lengths occurred when a continuous infusion of oxytocin was given into the jugular vein from Days 15 to 21. Instead a pattern of progesterone, PGFM and LH concentrations consistent with normal luteolysis and ovulation was recorded. However, in 4 out of 8 heifers described by Kotwica et al. (1988) PGFM was secreted at the initiation of infusion, suggesting that endometrial oxytocin receptors were present at the start of the experiment. By contrast, when Lafrance \& Goff (1985) gave single intravenous injections of 100 i.u. oxytocin to heifers on Day 13 they did not record any such increase in PGFM levels up to $90 \mathrm{~min}$ after injection. Lafrance \& Goff (1988) subsequently showed that in ovariectomized heifers a period of exposure to progesterone of $7-14$ days was required to induce PGF-2 $\alpha$ release in response to oestradiol and oxytocin. No change in PGFM output was noted on Day 10 at the start of oxytocin infusions in the present experiment, the concentrations remaining consistent with mid-cycle basal release rates measured by other workers (Kindahl et al., 1976b, 1984; Betteridge et al., 1984). The discrepancy between our results and those of Kotwica et al. (1988) therefore may reflect the fact that in the present study oxytocin infusion began at a stage of the cycle before any rise in endometrial oxytocin receptor concentrations. Future experiments to measure uterine oxytocin receptors and prostaglandin output at the predicted time of luteolysis should help to resolve this point. 
Mean plasma oxytocin concentrations measured in the control animals were consistent with published values of Walters et al. (1984) $(2 \cdot 7 \pm 0.5 \mathrm{pg} / \mathrm{ml}$ for mid-luteal levels) and Schallenberger et al. (1984) $(8.2 \pm 1.2 \mathrm{pg} / \mathrm{ml}$ for heifers on Day 12 of the cycle). Mean plasma concentrations achieved by animals receiving oxytocin from minipumps ranged from 12 to 30 times these figures, and should therefore be considered as pharmacological. However, evidence from post-infusion incubation of minipumps and oxytocin plasma concentrations near the end of the infusions suggested that, in 2 animals (Heifers 3 and 6), the flow rate of the pumps had dropped before removal. These 2 animals and Heifer 1 all had cycles extended by $2-5$ days only, whereas the 2 animals (Heifers 8 and 11 ) with pumps still working at flow rates of $>11 \mu \mathrm{g} / \mathrm{h}$ at removal had their cycles extended by $5-6$ days. It is possible that the observed extensions to luteal life-span were limited by the infusion time and might be extended further by a longer period of infusion.

The high concentrations of oxytocin in the circulation did not appear to affect follicular development, as progesterone profiles from treated heifers after pump withdrawal showed that luteolysis was followed by a rise in progesterone consistent with ovulation and luteinization.

There was no change in progesterone output at the start of oxytocin infusion (Fig. 3), suggesting that oxytocin did not have a direct effect on progesterone release. In-vitro work by Tan et al. $(1982 \mathrm{a}, \mathrm{b})$ showed that low levels of exogenous oxytocin directly stimulated progesterone secretion from dispersed bovine and human luteal cells, whereas high levels had an inhibitory effect. However, these results could not be confirmed by Barrett (1987) using bovine luteal cells or by Richardson \& Masson (1985) using human luteal cells. Although our results do not show an effect of oxytocin on progesterone secretion, Walters et al. (1984) found that spontaneous pulses of oxytocin in the mid-luteal phase were accompanied by release of progesterone in vivo, suggesting that a common mechanism may exist for controlling secretion of both hormones.

We thank the D. R. Melrose Memorial Trust for Scholarship support (C.L.G., T.J.P.); Chris Smith, Lyle Starrit and Mrs Angela Bufton for skilled technical assistance; Ron Temple and Tony Dingle for care of the stock; Hoechst, Frankfurt, for the oxytocin; Liz Wheatley for typing the manuscript; and the AFRC, Arthur Hosier Trust and Hoechst for financial support.

\section{References}

Abdelgadir, S.E., Swanson, L.V., Oldfield, J.E. \& Stormshak, F. (1987) Prostaglandin $F_{2 u}$-induced reIcase of oxytocin from bovine corpora lutea in vitro. Biol. Reprod. 37, 550-555.

Armstrong, D.T. \& Hansel, W. (1959) Alteration of the bovine estrous cycle with oxytocin. J. Dairy $S c i$. 42, $533-542$.

Barrett, J. (1987) In vitro studies of bovine ovarian oxytocin. Ph.D. thesis, University of Bristol.

Betteridge, K.J., Randall, G.C.B., Eaglesome, M.D. \& Sugden, E.A. (1984) The influence of pregnancy on $\mathrm{PGF}_{2 a}$ secretion in cattle. Anim. Reprod. Sci. 7, $195-216$.

Flint, A.P.F. \& Sheldrick, E.L. (1985) Continuous infusion of oxytocin prevents induction of uterine oxytocin receptor and blocks luteal regression in cyclic ewes. J. Reprod. Fert. 75, 623-631.

Flint, A.P.F. \& Sheldrick, E.L. (1986) Ovarian oxytocin and the maternal recognition of pregnancy. $J$. Reprod. Fert. 76, 831-839.

Hansel, W. \& Wagner, W.C. (1960) Luteal inhibition in the bovine as a resuit of oxytocin injection, uterine dilatation and intrauterine infusions of seminal and preputial fluids. J. Dairy Sci. 43, 796-805.
Hunter, M.G., Southee, J.A., McLeod, B.J. \& Haresign, W. (1986) Progesterone pretreatment has a direct effect on GnRH-induced preovulatory follicles to determine their ability to develop into normal corpora lutea in anoestrous ewes. J. Reprod. Fert. 76, 349--363.

Ivell, R. \& Richter, D. (1984) The gene for the hypothalamic peptide hormone oxytocin is highly expressed in the bovine corpus luteum: biosynthesis, structure and sequence analysis. EMBO J. 3, 2351-2354.

Kaker, M.L., Murray, R.D. \& Dobson, H. (1984) Plasma hormone changes in cows during induced or spontaneous calvings and the early post-partum period. Vet. Rec. 115, 378-382.

Kindahl, H., Edqvist, L.E., Granström, E. \& Bane, A. (1976a) The release of prostaglandin $\mathbf{F}_{2 a}$ as reflected by 15-keto-13,14,-dihydroprostaglandin $F_{2 a}$ in the peripheral circulation during normal luteolysis in heifers. Prostaglandins 11, 871-878.

Kindahl, H., Edqvist, L.E., Bane, A. \& Granström, E. (1976b) Blood levels of progesterone and 15-keto13,14-dihydro-prostaglandin $\mathrm{F}_{2 \alpha}$ during the normal oestrous cycle and early pregnancy in heifers. Acta endocr., Copenh. 82, 134-149. 
Kindahl, H., Basu, S., Fredriksson, G., Goff, A., Kunarongkrit, A. \& Edqvist, L.E. (1984) Level of prostaglandin $\mathrm{F}_{2 a}$ metabolites in blood and urine during early pregnancy. Anim. Reprod. Sci. 7, 133-148.

Kotwica, J., Schams, D., Meyer, H.H.D. \& Mittermeier, Th. (1988) Effect of continuous infusion of oxytocin on length of the oestrous cycle and luteolysis in cattle. J. Reprod. Fert. 83, 287-294.

Lafrance, M. \& Goff, A.K. (1985) Effect of pregnancy on oxytocin-induced release of prostaglandin $F_{2 a}$ in heifers. Biol. Reprod. 33, 1113-1119.

Lafrance, M. \& Goff, A.K. (1988) Effects of progesterone and oestradiol-17 $\beta$ on oxytocin-induced release of prostaglandin $\mathrm{F}_{2 \alpha}$ in heifers. J. Reprod. Fert. 82, 429436.

Oyedipe, E.O., Gustafsson, B. \& Kindahl, H. (1984) Blood levels of progesterone and 15-keto-13,14,dihydro prostaglandin $F_{2 u}$ during the oestrous cycle of oxytocin-treated cows. Theriogenology 22, 329 340 .

Richardson, M.C. \& Masson, G.M. (1985) Lack of direct inhibitory action of oxytocin on progesterone production by dispersed cells from human corpus luteum. J. Endocr. 104, 149-151.

Schallenberger, E., Schams, D., Bullermann, B. \& Walters, D.L. (1984) Pulsatile secretion of gonadotrophins, ovarian steroids and ovarian oxytocin during prostaglandin-induced regression of the corpus luteum in the cow. J. Reprod. Fert. 71, 493-501.

Schams, D. (1987) Luteal pepides and intercellular communication. J. Reprod. Fert., Suppl. 34, 87-99.

Schams, D. \& Karg, H. (1982) Hormonal responses following treatment with different prostaglandin analogues for estrous cycle regulation in cattle. Theriogenology 17, 499-513.
Swann, R.W., O'Shaughnessy, P.J., Birkett, S.D., Wathes, D.C., Porter, D.G. \& Pickering, B.T. (1984) Biosynthesis of oxytocin in the corpus luteum. FEBS Lett. 174, 262-266.

Tan, G.J.S., Tweedale, R. \& Biggs, J.S.G. (1982a) Effects of oxytocin on the bovine corpus luteum of early pregnancy. J. Reprod. Fert. 66, 75-78.

Tan, G.J.S., Tweedale, R. \& Biggs, J.S.G. (1982b) Oxytocin may play a role in the control of the human corpus luteum. J. Endocr. 95, 65-70.

Vighio, G.H. \& Liptrap, R.M. (1986) Plasma concentrations of oxytocin, prostaglandin and ovarian steroids during spontaneous luteolysis in the cow. Dom. Anim. Endocr. 3, 209-215.

Walters, D.L. \& Schallenberger, E. (1984) Pulsatile secretion of gonadotrophins, ovarian steroids and ovarian oxytocin during the periovulatory phase of the oestrous cycle in the cow. J. Reprod. Fert. 71, $503-512$.

Walters, D.L., Schams, D. \& Schallenberger, E. (1984) Pulsatile secretion of gonadotrophins, ovarian steroids and ovarian oxytocin during the luteal phase of the oestrous cycle in the cow. $J$. Reprod. Fert. $\mathbf{7 1}$, 479-491.

Wathes, D.C., Swann, R.W., Birkett, S.D., Porter, D.G. \& Pickering, B.T. (1983) Characterization of oxytocin, vasopressin and neurophysin from the bovine corpus luteum. Endocrinology 113, 693-698.

Wathes, D.C., Swann, R.W., Porter, D.G. \& Pickering, B.T. (1986a) Oxytocin as an ovarian hormone. Current Topics in Neuroendocrinology 6, 129-151.

Wathes, D.C., Guldenaar, S.E.F., Swann, R.W., Webb, R., Porter, D.G. \& Pickering, B.T. (1986b) A combined radioimmunoassay and immunocytochemical study of ovarian oxytocin production during the periovulatory period in the ewe. J. Reprod. Fert. 78, $167-183$.

Received 17 August 1988 